\title{
Evaluation of the Effect of Gurusa, a Ugandan Cereal-Based Fermented Food on Serum Lipid Profile and Body Weight of Wistar Albino Rats
}

\author{
Atamgba Agbor Asuk ${ }^{1,2 *}$, Abbas Kisambira², Muhammad Lubowa², Denis Ssenabulya² \\ ${ }^{1}$ Department of Medical Biochemistry, Cross River University of Technology, Okuku Campus, \\ Calabar, Nigeria \\ ${ }^{2}$ Department of Food Science and Nutrition, Islamic University in Uganda, Mbale, Uganda \\ Email: "raphaelasuk@gmail.com
}

Received 16 March 2016; accepted 24 April 2016; published 27 April 2016

Copyright (C) 2016 by authors and Scientific Research Publishing Inc.

This work is licensed under the Creative Commons Attribution International License (CC BY). http://creativecommons.org/licenses/by/4.0/

cC) (i) Open Access

\section{Abstract}

The effect of Gurusa, a fermented traditional food on lipid profile and body weight was investigated. Thirty male albino rats weighing between 75 - $115 \mathrm{~g}$ assigned into five study groups designated $\mathrm{A}$ to $E(n=6)$ were fed 20 g of prepared pellets and tap water given ad libitum. The animals were served graded doses of Gurusa. Group A was served $100 \%$ rat chow pellets (made of maize bran); groups B, C and D were given pellets of $75 \%$ rat chow and $25 \%$ Gurusa, $50 \%$ rat chow and $50 \%$ Gurusa, $25 \%$ rat chow and $75 \%$ Gurusa respectively while group E was served $100 \%$ Gurusa. The lipid profile showed a dose dependent effect of Gurusa administration as one moves down the groups. Group D had a reverse action of group B and showed significant $(P<0.05)$ increase in TC, TG and HDL compared to groups $A$ and $B$ but a significant $(P<0.05)$ decrease in LDL compared to group B. Weight changes in group B produced a significant $(P<0.05)$ increase in MWI and GR compared to the other groups. There was no significant $(P \geq 0.05)$ difference in MWI and GR of group D when compared with group $A$. However group $C$ showed significant $(P<0.05)$ increase in MWI and GR when compared with group A. Gurusa consumption alters both lipid profile and body weight and its combination with maize bran or other foods rich in dietary fibre, have potential to serve therapeutic purposes in the prevention of atherosclerosis and obesity depending on the intended objective.

\section{Keywords}

Traditional Diet, Atherosclerosis, Obesity, Proximate Composition, Nubians

\footnotetext{
${ }^{*}$ Corresponding author.
}

How to cite this paper: Asuk, A.A., Kisambira, A., Lubowa, M. and Ssenabulya, D. (2016) Evaluation of the Effect of Gurusa, a Ugandan Cereal-Based Fermented Food on Serum Lipid Profile and Body Weight of Wistar Albino Rats. Food and Nutrition Sciences, 7, 284-293. http://dx.doi.org/10.4236/fns.2016.74030 


\section{Introduction}

Fermentation is a desirable process involving the biochemical modification of the primary food matrix by enzymes inherent in microorganisms. Fermentation of cereals generally leads to an improvement in the shelf life, texture, taste and aroma, nutritional value and digestibility and significantly lowers the content of anti-nutritional factors in cereals [1]. The microorganism responsible for the fermentation may be the micro-flora indigenously present on the substrate or they may be added as a starter culture [2]. Fermented foods are produced worldwide; however, the main fermentation processes or types are alcoholic, lactic acid and acetic acid fermentations [3].

In Africa, every country and/or community has its recipe for fermentation of indigenous foods and drinks [4]. A variety of cereals are used either singly or mixed to produce a number of fermented beverages and foods [5]. In Uganda, the traditional cereal-based fermented beverages and foods such as Gurusa, are still prevailing in both rural and some urban communities.

Gurusa is a traditional fermented, baked pancake with a spongy texture common among the Nubian community of Uganda. It is a product of fermentation composed of wheat and maize flours, of which wheat is the most dominant ingredient. Gurusa, among the Nubians is considered the most precious food which is normally served as a component on main course meals or as a snack with tea. The Nubians are believed to have their origin in Southern Egypt and Sudan and currently distributed in Kenya and Uganda [6]. In Uganda, the Nubians were brought by the British way back in the colonial period [6], and now are distributed in areas of Bombo, Namuwongo, Kibuli, Naguru, Arua and Entebbe. Wheat, a component of Gurusa, has a high content of amylopectin (three-fourths of total starch) that yields a lot of glucose (about 1000 molecules per molecule of amylopectin) compared to amylose (200 molecules of glucose). This gives it a high glycaemic index (GI) which can be implicated in hyperglycaemia and possibly diabetes, cardiovascular diseases and even cancer [7], however, fermentation has been associated with improved quality and nutrient content of a product. It reduces the glycaemic index of a food material thereby improving the blood glucose control, the blood lipid profile, and fibrinolytic activity [8].

There is indeed a relationship between the type of diet consumed and the health status of an individual, as diets rich in saturated fatty acids increase the cholesterol level in the body. But such diets are also appetizing and cause an individual to increase their consumption. This combined with poor lifestyle, increases the prevalence of bad cholesterol in the body (LDL-C). Many complications like atherosclerosis, coronary thrombosis or coronary artery disease have been linked to the deposition of excessive cholesterol in blood vessels, which has always been the initiative of most health institutions and organizations to combat such complications. Epidemiological studies have revealed that by 2015 one in three deaths worldwide will be due to cardiovascular disease [9], and the prevailing factors remain high levels of serum total cholesterol (TC), low-density lipoprotein (LDL), total triglyceride (TG) and decreased levels of high-density lipoprotein (HDL).

There are currently no available data showing the relationship between Gurusa consumption and lipid profile and body weight, therefore the determination of these parameters in albino rats fed Gurusa might help in establishing a kind of relationship. The outcome of this research will help communities especially those of the Nubians to make informed choices about the health status of the foods they consume.

\section{Materials and Methods}

\subsection{Equipment, Chemicals and Reagents}

Material used in the laboratory included crucibles, drying oven, desiccator, weighing balance, forceps, glass rods, steam bath, distillation flask, Buchner flasks, sintered glass crucible, cling film or aluminium foil, phenolphthalein indicator, muffle furnace, water bath, hot plate, Soxhlet distillation flask and extractor, fat-free extraction thimble and reflux condenser.

All chemicals and reagents used in this work were of analytical grade.

\subsection{Raw Materials and Preparation of Gurusa}

\subsubsection{Raw Materials}

The raw materials used included refined wheat flour, maize flour, baking powder, sugar and cooking oil. These were obtained from Bam Supermarket and Mbale Central Market in Mbale town, Uganda. 


\subsubsection{Preparation of Gurusa}

The preparation of Gurusa was done based on interaction with experienced traditionalists of the local Nubian community. To a fermenting bowl, $500 \mathrm{~g}$ of wheat flour was mixed with $250 \mathrm{~g}$ of maize flour, and $750 \mathrm{~mL}$ of lukewarm water ( $37^{\circ} \mathrm{C}$ ) was then added and mixed to make a thick paste referred to as Lagini Gurusa (Figure 1). The bowl was then placed in a water bath maintained at $39^{\circ} \mathrm{C}$, and was allowed to ferment (Fulu) for 12 hours. To the fermented Lagini Gurusa was added $250 \mathrm{~g}$ of wheat flour, $60 \mathrm{~g}$ of sugar, $125 \mathrm{~g}$ of maize flour and 200 $\mathrm{mL}$ of hot water and thoroughly mixed to ensure consistency. The baking tray was preheated, and $6 \mathrm{~g}$ of baking powder was then added to the Lagini Gurusa and mixed, where, small quantities were then poured to a greased preheated baking tray and spread to make thin walled pancakes and this was added one at a time (Figure 2).

\subsection{Proximate Analysis of Maize Bran and Gurusa}

The analysis of the proximate composition of maize bran, Lagini Gurusa and Gurusa was carried out using the official methods of analysis of the Association of Official Analytical Chemists [10].

\section{Energy Value}

The energy value of Gurusa was obtained from the formulae given below:

$$
\text { Energy value }(\mathrm{kJ} / 100 \mathrm{~g})=[(37 \times \text { fat })+(17 \times \text { carbohydrate })+(17 \times \text { protein })][11] \text {. }
$$

\subsection{Sensory Evaluation of Formulated Gurusa}

Sensory evaluation of the product sample was done at Islamic University in Uganda from the Food science and Nutrition laboratory. The panellists $(n=30)$ were from the Department of Food Science and Nutrition and the University community. They were recruited on the criteria that they did not have any food allergies, and no information was availed to the panellists on the amounts and ingredients in the food samples. This was done to minimize biasness. For sample evaluation, $50 \mathrm{~g}$ of the product samples from each formulation was placed into plastic disposable plates coded "A" and "B". Samples from each formulation were served to each panellist. Samples were presented to panellists in random order. In addition, panellists were provided with sensory evaluation questionnaire to be filled in and purified water for rinsing their mouth in between sample tests. Panellists were requested to consume the sample and rinse their mouth with the water provided between samples to minimize any residual effect. A 5-point hedonic scale ranging from dislike definitely to like definitely was used to evaluate the acceptance of the two product samples based on the attributes of odour, taste, balance of sweetness and acidity and general acceptability. The mean scores were then determined and recorded (where 1, 2, 3, 4 and 5 points represented dislike definitely, dislike mildly, neither like nor dislike, like mildly and like definitely respectively).

\subsection{Animal Experiment}

Male albino rats were obtained from the animal house, Department of Biology, Tororo Girls College, Tororo,

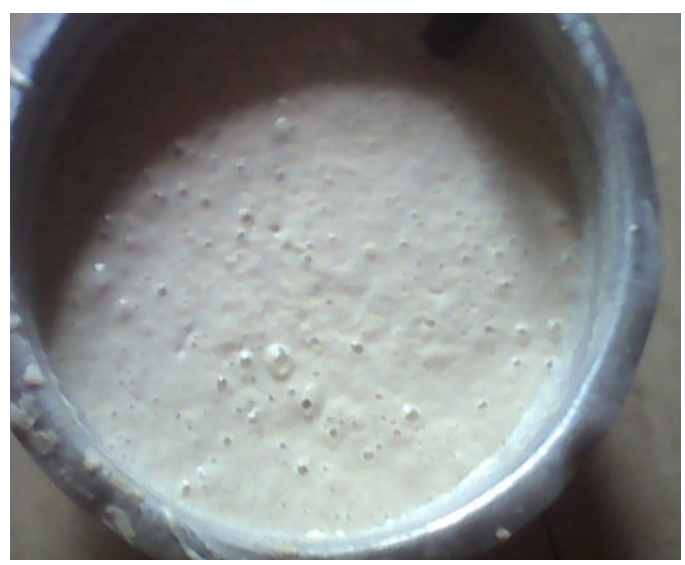

Figure 1. Fermenting Lagini Gurusa during preparation of Gurusa. 


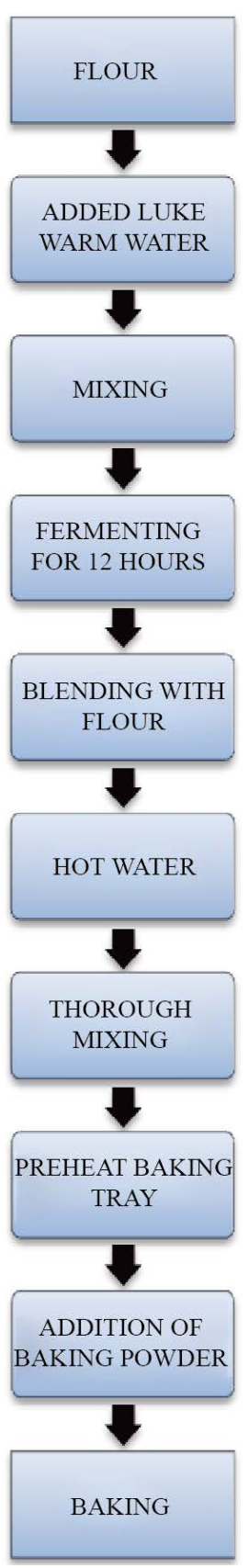

Figure 2. Process flow chart for Gurusa making.

Uganda. The animals were kept in well-ventilated laboratory cages with $12 \mathrm{~h}$ day/night cycles and allowed to acclimatize for a week and fed with rat pellet of maize bran and given water ad libitum, until they weighed between 75 - $115 \mathrm{~g}$ before being used for the animal experiment. The principles of laboratory animal care were dully followed.

\subsubsection{Preparation of Gurusa Pellets for Animal Feed}

Prepared Gurusa was ground to the least particle size, and then the different concentrations were prepared based on $100 \mathrm{~g}$ weight, blended and mixed with $10 \mathrm{~mL}$ of distilled water. The mixture was then moulded into pellets of five grams and oven dried at $45^{\circ} \mathrm{C}$ for $4 \mathrm{~h}$ to obtain the Gurusa feed. Feeds were weighed from the prepared pellets daily for administration to the various experimental groups. 


\subsubsection{Experimental Design}

In this experiment, male albino rats were used as models. The experiment involved the use of 30 animals which were divided into five groups of 6 animals each. The animals in each group were placed in separate cages.

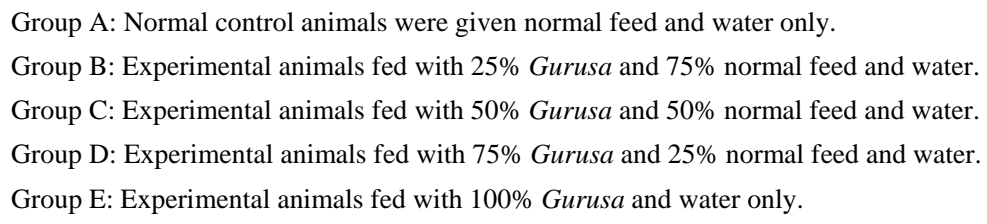

Each of the animals were fed $20 \mathrm{~g}$ of the prepared pellets and the weights of the animals were measured daily with the use of DT-1001A electronic weighing balance before fresh feeds could be administered and the weights of the actual feeds that were eaten were determined by weighing the remainder of the feeds. The experiment was set for 21 days sub-chronic evaluation [12] [13], after which, the animals were subjected to an overnight fast of $14 \mathrm{~h}$ penultimate to the day of sacrifice after anaesthesia. Principles of laboratory animal care according to ETS-123 [14] were applied. All experiments and procedures were examined and approved by the University Ethics Committee.

\subsection{Biochemical Analysis of Blood Samples Obtained from Experimental Animals}

Blood from the animals was obtained by cardiac puncture using a $3 \mathrm{~mL}$ syringe with a $23 \mathrm{G}, 1$ needle [15]. The blood was collected into $4.0 \mathrm{~mL}$ BD vacutainers CAT (REF 369032), and placed in a cool box and kept in a refrigerator at $4^{\circ} \mathrm{C}$ until required for use.

\section{Serum Lipid Profile Determination}

The serum HDL, total cholesterol and triglycerides were determined using the automated machine Human Star 180 chemical analyzer with all concentrations given in $\mathrm{mg} / \mathrm{dL}$. The LDL cholesterol was determined by difference [16], as shown below:

$$
\text { Total Chol. -(triglyc/5.0) - HDL chol. (mg/dL) }
$$

\subsection{Statistical Analysis}

Data obtained from the experiment was presented as mean \pm SEM after calculation using Microsoft Office Excel 2007. The data was also subjected to a one way analysis of variance (ANOVA) and post hoc (LSD) and independent-sample T-test for levels of significance using SPSS version16.0. The levels of significance were accepted at $P<0.05$.

\section{Results}

\subsection{Results for Proximate Composition of Maize Bran, Lagini Gurusa and Gurusa}

The proximate parameters analyzed included crude protein, crude fat, moisture content, ash content, total carbohydrate, crude fibre, total reducing sugar and energy value. The results for proximate composition of maize bran, Lagini Gurusa and Gurusa are shown in Table 1.

\subsection{Results of Sensory Evaluation}

The sensory attributes of Gurusa evaluated included odour (flavour), taste, balance of sweetness and acidity, and overall acceptability for samples A and B. Results of the sensory evaluation of the two Gurusa samples are given in Table 2. There was no significant $(P \geq 0.05)$ difference in the odour and the balance of sweetness and acidity between samples A and B but there was a significant $(P<0.05)$ difference in taste and the overall acceptability between the samples.

\subsection{Results of Serum Lipid Profile of Albino Rats Fed Gurusa}

The serum lipid parameters determined included Total cholesterol (TC), Total triglycerides (TG), Low density 
Table 1. Proximate composition of maize bran, Lagini Gurusa and Gurusa [w/w dry mass basis (\%)].

\begin{tabular}{cccc}
\hline Composition & Maize bran & Lagini Gurusa (Unfermented) & Gurusa (fermented and baked) \\
\hline Crude protein & $9.85 \pm 0.06^{\mathrm{a}}$ & $10.65 \pm 0.06^{\mathrm{b}}$ & $12.88 \pm 0.05^{\mathrm{c}}$ \\
Crude fat & $11.66 \pm 0.02^{\mathrm{a}}$ & $0.54 \pm 0.01^{\mathrm{b}}$ & $0.20 \pm 0.01^{\mathrm{c}}$ \\
Moisture content & $16.01 \pm 0.09^{\mathrm{a}}$ & $55.23 \pm 0.06^{\mathrm{b}}$ & $49.25 \pm 0.02^{\mathrm{c}}$ \\
Ash content & $4.37 \pm 0.01^{\mathrm{a}}$ & $0.23 \pm 0.01^{\mathrm{b}}$ & $0.43 \pm 0.01^{\mathrm{c}}$ \\
Crude fibre & $13.29 \pm 0.11^{\mathrm{a}}$ & $0.36 \pm 0.01^{\mathrm{b}}$ & $0.28 \pm 0.01^{\mathrm{b}}$ \\
Total reducing sugar & $19.39 \pm 0.12^{\mathrm{a}}$ & $40.71 \pm 0.18^{\mathrm{b}}$ & $30.34 \pm 0.16^{\mathrm{c}}$ \\
Total carbohydrate & $58.12 \pm 0.08^{\mathrm{a}}$ & $33.35 \pm 0.07^{\mathrm{b}}$ & $37.25 \pm 0.07^{\mathrm{c}}$ \\
Energy (kJ/100g) & $1586.83 \pm 1.73^{\mathrm{a}}$ & $768.12 \pm 0.78^{\mathrm{b}}$ & $859.47 \pm 0.20^{\mathrm{c}}$ \\
\hline
\end{tabular}

Values are mean $\pm \mathrm{SEM} ; \mathrm{n}=3$.

a,b,c Values with different superscripts are significantly different at $P<0.05$.

Table 2. Sensory evaluation.

\begin{tabular}{|c|c|c|c|c|c|}
\hline Samples & Parameter & Odour & Taste & Balance of sweetness and acidity & Overall acceptability \\
\hline & A & $4.00 \pm 0.18^{\mathrm{a}}$ & $3.42 \pm 0.21^{\mathrm{a}}$ & $3.42 \pm 0.24^{\mathrm{a}}$ & $3.53 \pm 0.22^{\mathrm{a}}$ \\
\hline & B & $4.58 \pm 0.15^{\mathrm{a}}$ & $4.84 \pm 0.08^{\mathrm{b}}$ & $4.37 \pm 0.18^{\mathrm{a}}$ & $4.70 \pm 0.12^{b}$ \\
\hline
\end{tabular}

Values are mean \pm SEM; $\mathrm{n}=30$.

${ }^{\mathrm{a}, \mathrm{b}}$ Values with different superscripts are significantly different at $P<0.05$.

lipoprotein (LDL), High density lipoprotein (HDL) and Low density lipoprotein to High density lipoprotein (LDL/HDL) ratio for all animal groups. The results of serum lipid profile of albino rats are indicated in Table 3. The TC values showed no significant $(P \geq 0.05)$ difference between groups $\mathrm{A}, \mathrm{B}$ and $\mathrm{C}$ as well as between groups $\mathrm{D}$ and $\mathrm{E}$, but there was a significant difference in TC values between groups $\mathrm{A}, \mathrm{B}$, and $\mathrm{C}$ compared with groups $\mathrm{D}$ and $\mathrm{E}$ The highest TC value was observed in group D $(148.33 \pm 2.25)$ whereas the least in group $\mathrm{B}$ $(119.00 \pm 1.37)$.

The TG values showed a significant $(P<0.05)$ difference between group A and the rest of the groups. The TG values of group B was significantly $(P<0.05)$ decreased compared with the rest of the groups but there was no significant $(P \geq 0.05)$ difference between groups $\mathrm{C}$ and $\mathrm{D}$ as well as between $\mathrm{D}$ and $\mathrm{E}$. The highest TG value was observed in group E (125.25 \pm 4.04$)$ whereas the least in group B (62.00 \pm 3.98$)$.

The HDL values showed a significant $(P<0.05)$ difference between group A compared with groups $\mathrm{B}, \mathrm{C}$ and D but no significant $(P \geq 0.05)$ difference when compared with group E. The HDL values for groups $\mathrm{B}$ and $\mathrm{C}$ were significantly $(P<0.05)$ decreased while that of group $\mathrm{D}$ was significantly $(P<0.05)$ increased compared with the rest of the groups. The highest HDL value was observed in group D $(96.33 \pm 0.62)$ whereas the least HDL in group B $(62.00 \pm 2.06)$.

The LDL values showed no significant $(P \geq 0.05)$ difference between groups $\mathrm{A}, \mathrm{C}$ and $\mathrm{D}$ as well as between $\mathrm{B}$ and $\mathrm{E}$, but when groups $\mathrm{A}, \mathrm{C}$ and $\mathrm{D}$ were compared with $\mathrm{B}$ and $\mathrm{E}$, there was a significant $(P<0.05)$ difference between them. The highest LDL value was observed in group B (44.6 \pm 3.09$)$ whereas the least in group A (27.55 \pm 2.99).

There was no significant $(P \geq 0.05$ ) difference in LDL/HDL ratios between groups $\mathrm{A}, \mathrm{D}$ and $\mathrm{E}$ as well as between groups $\mathrm{B}, \mathrm{C}$ and $\mathrm{E}$, however group $\mathrm{D}$ was significantly $(P<0.05)$ decreased compared with groups $\mathrm{B}$, C and $\mathrm{E}$ The highest LDL/HDL ratio value was observed in group B $(0.730 \pm 0.079)$ whereas the least LDL/HDL ratio value was shown in group $\mathrm{D}(0.297 \pm 0.013)$.

\subsection{Results of Body Weight of Rats during Animal Experimentation}

Weight parameters taken during animal experimentation included mean weight increase (MWI) and growth rate (GR) for albino rats in all groups on the initial day and days 4, 8, 12, 16 and 20. The results of body weight changes of rats are presented in Table 4 . The body weights showed a significant $(P<0.05)$ difference between groups $\mathrm{A}, \mathrm{B}$ and $\mathrm{E}$ on the initial day and day 4 . There was no significant $(P \geq 0.05)$ difference for body weights 
Table 3. Serum lipid profile of albino rats fed Gurusa.

\begin{tabular}{clccccc}
\hline Group & Parameter & $\begin{array}{c}\text { TC } \\
(\mathbf{m g} / \mathbf{d L})\end{array}$ & $\begin{array}{c}\text { TG } \\
(\mathbf{m g} / \mathbf{d L})\end{array}$ & $\begin{array}{c}\text { HDL } \\
(\mathbf{m g} / \mathbf{d L})\end{array}$ & $\begin{array}{c}\text { LDL } \\
(\mathbf{m g} / \mathbf{d L})\end{array}$ & LDL/HDL Ratio \\
\hline & A & $123.75 \pm 1.52^{\mathrm{a}}$ & $92.25 \pm 2.56^{\mathrm{a}}$ & $77.75 \pm 0.96^{\mathrm{a}}$ & $27.55 \pm 2.99^{\mathrm{a}}$ & $0.356 \pm 0.043^{\mathrm{ac}}$ \\
$\mathbf{B}$ & $119.00 \pm 1.37^{\mathrm{a}}$ & $62.00 \pm 3.98^{\mathrm{b}}$ & $62.00 \pm 2.06^{\mathrm{b}}$ & $44.60 \pm 3.09^{\mathrm{b}}$ & $0.730 \pm 0.079^{\mathrm{b}}$ \\
C & $122.67 \pm 2.62^{\mathrm{a}}$ & $110.33 \pm 4.09^{\mathrm{c}}$ & $64.33 \pm 3.79^{\mathrm{b}}$ & $36.27 \pm 1.92^{\mathrm{ab}}$ & $0.578 \pm 0.059^{\mathrm{b}}$ \\
D & $148.33 \pm 2.25^{\mathrm{b}}$ & $117.00 \pm 1.22^{\mathrm{cd}}$ & $96.33 \pm 0.62^{\mathrm{c}}$ & $28.60 \pm 1.39^{\mathrm{a}}$ & $0.297 \pm 0.013^{\mathrm{c}}$ \\
E & $145.50 \pm 0.56^{\mathrm{b}}$ & $125.25 \pm 4.04^{\mathrm{d}}$ & $77.50 \pm 1.25^{\mathrm{a}}$ & $42.95 \pm 2.57^{\mathrm{b}}$ & $0.557 \pm 0.042^{\mathrm{ab}}$ \\
\hline
\end{tabular}

Values are mean \pm SEM; $\mathrm{n}=6$.

a,b,c,d Values with different superscripts are significantly different at $P<0.05$.

$\mathrm{TC}=$ total cholesterol, TG = total triglyceride, HDL = high density lipoprotein, $\mathrm{LDL}=$ low density lipoprotein.

Table 4. Weight changes of albino rats fed Gurusa.

\begin{tabular}{|c|c|c|c|c|c|c|c|c|}
\hline \multirow[b]{2}{*}{ Group } & \multirow{2}{*}{$\begin{array}{c}\text { Initial body } \\
\text { weight (g) }\end{array}$} & $\begin{array}{c}\text { Body } \\
\text { weight (g) }\end{array}$ & $\begin{array}{c}\text { Body } \\
\text { weight (g) }\end{array}$ & $\begin{array}{c}\text { Body } \\
\text { weight (g) }\end{array}$ & $\begin{array}{c}\text { Body } \\
\text { weight (g) }\end{array}$ & $\begin{array}{c}\text { Body } \\
\text { weight (g) }\end{array}$ & \multirow[t]{2}{*}{ MWI (\%) } & \multirow[t]{2}{*}{ GR (\%) } \\
\hline & & Day 4 & Day 8 & Day 12 & Day 16 & Day 20 & & \\
\hline A & $96.03 \pm 5.35^{a}$ & $99.83 \pm 5.30^{\mathrm{a}}$ & $101.30 \pm 5.14^{\mathrm{ab}}$ & $104.70 \pm 3.97^{\mathrm{ab}}$ & $113.07 \pm 5.01^{\mathrm{ab}}$ & $115.83 \pm 4.62^{\mathrm{a}}$ & $20.98 \pm 2.86^{\mathrm{ac}}$ & $99.00 \pm 10.9^{\text {ad }}$ \\
\hline B & $77.27 \pm 0.92^{b}$ & $85.20 \pm 1.07^{\mathrm{b}}$ & $92.53 \pm 0.64^{b}$ & $100.23 \pm 0.35^{\mathrm{b}}$ & $104.73 \pm 0.43^{b}$ & $111.53 \pm 0.93^{\mathrm{a}}$ & $44.45 \pm 2.84^{b}$ & $171.33 \pm 9.12^{\mathrm{b}}$ \\
\hline C & $96.63 \pm 2.49^{\mathrm{a}}$ & $100.50 \pm 2.89^{\mathrm{a}}$ & $105.50 \pm 2.74^{\mathrm{a}}$ & $110.37 \pm 2.19^{\mathrm{ab}}$ & $108.50 \pm 1.42^{\mathrm{ab}}$ & $108.10 \pm 1.44^{\mathrm{a}}$ & $12.02 \pm 2.31^{\mathrm{a}}$ & $57.33 \pm 10.2^{c}$ \\
\hline D & $96.77 \pm 2.05^{\mathrm{a}}$ & $96.93 \pm 1.94^{\mathrm{a}}$ & $106.43 \pm 1.33^{\mathrm{a}}$ & $111.50 \pm 0.45^{\mathrm{a}}$ & $116.33 \pm 1.47^{\mathrm{a}}$ & $118.80 \pm 2.60^{\mathrm{a}}$ & $22.76 \pm 0.10^{c}$ & $110.17 \pm 2.76^{\mathrm{d}}$ \\
\hline $\mathbf{E}$ & $114.1 \pm 5.47^{\mathrm{c}}$ & $120.50 \pm 2.82^{c}$ & $125.33 \pm 2.97^{c}$ & $128.03 \pm 3.75^{c}$ & $127.93 \pm 3.73^{c}$ & $128.77 \pm 3.79^{b}$ & $13.20 \pm 3.05^{\mathrm{ac}}$ & $73.33 \pm 14.0^{\mathrm{acd}}$ \\
\hline
\end{tabular}

Values are mean \pm SEM; $\mathrm{n}=6$.

a,b,c,d Values with different superscripts are significantly different at $P<0.05$.

MWI = Mean weight increase, GR = Growth rate.

on the initial day, day 4, 8, 12, 16 and 20 between groups A, C and D. However, at day 20, there was no significant $(P \geq 0.05)$ difference in body weights between all the groups except with group $\mathrm{E}$ which remained significantly $(P<0.05)$ increased.

The MWI values showed a significant $(P<0.05)$ increase in group B compared with the rest of the groups, whereas group $\mathrm{D}$ showed no significant $(P \geq 0.05)$ difference with the rest of the groups except $\mathrm{B}$ and $\mathrm{C}$. The highest MWI value was observed in group B (44.45 \pm 2.84$)$ whereas the least MWI value was shown in group C $(12.02 \pm 2.31)$.

The GR values followed a similar pattern as the MWI except that there was a significant $(P<0.05)$ difference in this case between groups A and C. The highest GR value was observed in group B (171.33 \pm 9.12$)$ whereas the least GR value was shown in group C (57.33 \pm 10.2$)$.

\section{Discussion}

The fermentation of Lagini Gurusa brought about the modification of its proximate composition. The proximate analysis of Gurusa revealed higher protein content than the unfermented Lagini Gurusa even more so than grains of wheat and maize (10.6\% and $9.8 \%$ respectively) as was reported by Alias \& Linden [17]. There was also increased ash content which is a measure of its mineral content. This is so because fermentation leads to increased concentration of vitamins, minerals and protein especially when measured on dry weight basis [1]. The present research showed an increase in total carbohydrate and decrease in total reducing sugar. This observation was consistent with what was reported by Omemu [18] on the fermentation of maize for ogi production. The fat content of Gurusa was decreased compared with the unfermented dry weight matter. This is in agreement with earlier reports that fat content of fermented products are decreased [19] [20]. The fibre content for Gurusa was decreased compared to the dry weight of the raw material [21]. Omemu [18] and Wizna et al. [21] have all reported decreased levels in crude fibre content of fermented foods. Possible reason for this decrease may be as a result of breakdown of resistant starch to soluble form [22]. High moisture content has been reported for fermented food products [18] [23] but the Gurusa produced had lower moisture content due to the fact that it was also baked after fermentation and this may have ultimately reduced the moisture content. 
The preferred form of Gurusa after sensory evaluation result was used for the administration to experimental animals. Biochemical analysis of serum lipid which included TC, TG, LDL and HDL was carried out at the end of the animal experiment. Total cholesterol is a direct cholesterol measurement of all cholesterol molecules in the blood and includes Low density lipoprotein (LDL), high density lipoprotein (HDL), and very low density lipoproteins (VLDL). The study on the lipid profile shows a direct relationship between the concentration of Gurusa and the TC and TG while that of HDL was not clear-cut as the HDL level dropped at $100 \%$ Gurusa administration. Conversely there was no clear-cut relationship between the concentration of Gurusa and the LDL and LDL/HDL ratio as they were increased at $100 \%$ Gurusa administration. Increased cholesterol and triglyceride levels have been implicated as risk factors in cardiovascular diseases [24]. In this work, there was general increase in TC with increased Gurusa administration from 25\% to $100 \%$ but there was no significant difference between the $0 \%$ administration (group A) and the $25 \%$, and $50 \%$ administration representing group $\mathrm{B}$ and $\mathrm{C}$ respectively. But these groups had increased LDL levels which have a strong correlation in cardiovascular diseases and a leading cause of death. The increased TC and TG in group D is strongly compensated with a significantly increased level in HDL and a decreased level in LDL. Fibre is known to bind with cholesterol during the formation of micelles, which results in reduction of cholesterol content of hepatic cells [25] [26], therefore the high level of fibre in group A diet may have created the difference in cholesterol level compared to groups D and $\mathrm{E}$ which was a fermented diet (Gurusa) with reduced fibre. In a recent report fermented soy milk was found to reduce both TC and TG levels in a dose dependent manner [27] but in this work only at 25\% Gurusa administration was this achieved to the extent that a significant decrease in serum TG occurred compared to the exclusively unfermented maize bran diet of group A. The 25\% Gurusa administration (group B) however did not fare well in LDL and HDL values as they were significantly increased and decreased respectively compared to group A. The LDL/HDL ratio also showed significant increase compared to group A. It is not quite clear why the increased TC and TG levels followed a dose dependent action of Gurusa administration but at 75\% Gurusa administration (group D), the HDL level was significantly increased and the LDL/HDL ratio was decreased compared to group A. These attributes are good for cardiovascular health. It is very likely then that increased serum TC and TG in group D may be as a result of synthesis of phospholipids in the liver [28]. However all values obtained in the experiment for lipid profile of Gurusa administration were within the desired ranges of $<200$ $\mathrm{mg} / \mathrm{dL}$ for both TC and TG, $<100 \mathrm{mg} / \mathrm{dL}$ for LDL and $\geq 60$ for HDL as reported by NHLBI [29].

MWI was directly related to GR. MWI and GR values were highest when LDL value was highest and HDL, TC and TG were lowest corresponding to $25 \%$ Gurusa administration. There was no clear-cut relation between lipid profile of Gurusa administration and weight gain but there appeared to be a regulated weight gain with increased Gurusa administration as there was a decrease in MWI and GR with increased Gurusa administration compared with control (group A) and group B (25\% Gurusa). Excessive weight gain has been used as a way of assessing for obesity [30]. Actually obesity is a condition characterized by excessive fat accumulation, resulting in metabolic impairments, and is associated with increased risk for diabetes, cardiovascular disease, disability, and mortality [31] [32]. Collective increased TG and TC with decreased HDL have been implicated in overweight [33]. But it was not clear in the present research as group B which gave the highest weight gain collectively had decreased levels of TC, TG and HDL. The others which had increased TC and TG had increased HDL and reduced weight gain. There was therefore no systematic or conventional pattern of serum lipid profile on Gurusa administration, but at 25\% Gurusa with 75\% maize bran administration decreased levels of TC, TG and HDL were observed with increased weight gain. Conversely at 75\% Gurusa with 25\% maize bran administration, there was increased TC, TG and HDL with regulated weight gain.

\section{Conclusion}

Gurusa consumption alters both lipid profile and body weight and its consumption with maize bran or other foods rich in dietary fibre have potential to serve therapeutic purposes in the prevention of atherosclerosis and obesity depending on the intended objective. This research may help people to make informed food choices especially as regards evaluating the health status of its indigenous foods.

\section{References}

[1] Kohajdova, Z. and Karovicova, J. (2007) Fermentation of Cereals for Specific Purpose. Journal of Food and Nutrition Research, 46, 51-57. 
[2] Harlander, S. (1992) Food Biotechnology. In: Lederberg, J., Ed., Encyclopedia of Microbiology, Academic Press, New York, 191-207.

[3] Blandino, A., Al-Aseeri, ME., Pandiella, SS., Cantero, D. and Webb, C. (2003) Cereal-Based Fermented Foods and Beverages. Food Research International, 36, 527-543. http://dx.doi.org/10.1016/S0963-9969(03)00009-7

[4] Abegaz, K., Beyene, F., Langsrud, T. and Narvhus, J.A. (2002) Indigenous Processing Methods and Raw Materials of Borde, an Ethiopian Traditional Fermented Beverage. Journal of Food Technology in Africa, 7, 59-64. http://dx.doi.org/10.4314/jfta.v7i2.19246

[5] Muyanja, C.M.B.K., Kikafunda, J.K., Narvhus, J.A., Helgetun, K. and Langsrud, T. (2003) Production Methods and Composition of Bushera: A Ugandan Traditional Fermented Cereal Beverage. African Journal of Food Agriculture Nutrition and Development, 3, 10-19. http://dx.doi.org/10.4314/ajfand.v3i1.19108

[6] Johnson, D.H. (2009) Tribe or Nationality? The Sudanese Diaspora and Kenyan Nubis. Journal of Eastern African Studies, 3, 112-131. http://dx.doi.org/10.1080/17531050802401825

[7] Wolever, T.M.S., Jenkins, D.J.A., Jenkins, A.L. and Josse, R.G. (1991) The Glycemic Index: Methodology and Clinical Implications. American Journal of Clinical Nutrition, 54, 846-854.

[8] Jarvi, A.E., Karlstrom, B.E., Granfeldt, Y.E., Bjorck, I.E., Asp, N.G. and Vessby, B.O. (1999) Improved Glycemic Control And Lipid Profile and Normalized Fibrinolytic Activity on a low-Glycemic Index Diet in Type 2 Diabetic Patients. Diabetes Care, 22, 10-18. http://dx.doi.org/10.2337/diacare.22.1.10

[9] Mahmood, S.S., Levy, D., Vasan, R.S. and Wang, T.J. (2014) The Framingham Heart Study and the Epidemiology of Cardiovascular Disease: A Historical Perspective. Lancet, 383, 999-1008. http://dx.doi.org/10.1016/S0140-6736(13)61752-3

[10] Association of Official Analytical Chemists (2010) Official Methods of Analysis of AOAC International. 18th Edition, Association of Official Analytical Chemists, Washington DC.

[11] FAO (2003) Food Energy-Methods of Analysis and Conversion Factors. FAO Food and Nutrition Paper 77, Food and Agriculture Organization of the United Nations, Rome.

[12] Balliett, M. and Burke, J.R. (2013) Changes in Anthropometric Measurements, Body Composition, Blood Pressure, Lipid Profile and Testosterone in Patients Participating in a Low-Energy Dietary Intervention. Journal of Chiropractic Medicine, 12, 3-14. http://dx.doi.org/10.1016/j.jcm.2012.11.003

[13] Radahmadi, M., Alaei, H., Sharfi, M.R. and Hosseini, N. (2013) The Effect of Synchronized Running Activity with Chronic Stress on Passive Avoidance Learning and Body Weights in Rats. International Journal of Preventive Medicine, 4, 430-437.

[14] European Treaty Series-No.123 (2005) European Convention for the Protection of Vertebrate Animals Used for Experimental and Other Scientific Purposes. Council of Europe, Strasbourg.

[15] Luzzi, M., Skoumbourdis, E., Baumans, V., Conte, A., Sherwin, C., Kerwin, A., Lang, T., Morton, D., Barley, J., Moreau, E., Weilenmann, R.F. and Reinhardt, V. (2005) Collecting Blood from Rodents: A Discussion by the Laboratory Animal Refinement and Enrichment Forum. Animal Technology and Welfare, 4, 99-102.

[16] Friedewald, W.T., Levy, R.I. and Fredrickson, D.S. (1972) Estimation of the Concentration of Low-Density Lipoprotein Cholesterol in Plasma, without Use of the Preparative Ultracentrifuge. Clinical Chemistry, 18, 499-502.

[17] Alias, C. and Linden, G. (1991) Food Biochemistry. Ellis Horwood Series in Food Science and Technology, Springer, New York.

[18] Omemu, A.M. (2011) Fermentation Dynamics during Production of ogi, a Nigerian Fermented Cereal Porridge. Report and Opinion, 3, 8-17.

[19] Khetarpaul, N. and Chauhan, B.M. (1989) Effect of Fermentation on Protein, Fat, Mineral and Thiamine Content of Pearl Millet. Plant Foods for Human Nutrition, 39, 169-177. http://dx.doi.org/10.1007/BF01091897

[20] FAO (1998) Carbohydrates in Human Nutrition: Report of a Joint FAO/WHO Expert Consultation. FAO Food and Nutrition Paper 66, Rome, 1-140.

[21] Wizna, H.A., Rizal, Y., Dharma, A. and Kompiang, P.I. (2009) Improving the Quality of Tapioca By-Products (Onggok) as Poultry Feed through Fermentation by Bacillus amyloliquefaciens. Pakistan Journal of Nutrition, 8, 1636-1640. http://dx.doi.org/10.3923/pjn.2009.1636.1640

[22] Hamad, A.M. and Fields, M.L. (1979) Evaluation of the Protein Quality and Available Lysine of Germinated and Fermented Cereals. Journal of Food Science, 44, 456-459. http://dx.doi.org/10.1111/j.1365-2621.1979.tb03811.x

[23] Makanjuola, O.M. and Ajayi, A. (2012) Effect of Natural Fermentation on the Nutritive Value and Mineral Composition of African Locus Beans. Pakistan Journal of Nutrition, 11, 11-13. http://dx.doi.org/10.3923/pjn.2012.11.13

[24] Miller, M., Stone, N.J., Ballantyne, C., Bittner, V., Criqui, M.H., Ginsberg, H.N., Goldberg, A.C., Howard, W.J., Jacobson, M.S., Kris-Etherton, P.M., Lennie, T.A., Levi, M., Mazzone, T. and Pennathur, S. (2011) Triglycerides and 
Cardiovascular Disease. Circulation, 123, 2292-2333. http://dx.doi.org/10.1161/CIR.0b013e3182160726

[25] Bowman, B.A. and Russell, R.M. (2006) Present Knowledge in Nutrition. International Life Science Institute, Washington DC.

[26] Narayan, S., Lakshmipriya, N., Vaidya, R., Bai, M.R., Sudha, R., Krishnaswamy, K., Unnikrishnan, R., Anjana, R.M. and Mohan, V. (2014) Association of Dietary Fiber Intake with Serum Total Cholesterol and Low Density Lipoprotein Cholesterol Levels in Urban Asian-Indian Adults with Type 2 Diabetes. Indian Journal of Endocrinology and Metabolism, 18, 624-630.

[27] Kobayashi, M., Hirahata, R., Egusa, S. and Fukuda, M. (2012) Hypocholesterolemic Effects of Lactic Acid-Fermented Soymilk on Rats Fed a High Cholesterol Diet. Nutrients, 4, 1304-1316. http://dx.doi.org/10.3390/nu4091304

[28] Guyton, A.C. and Hall, J.E. (2004) Textbook of Medical Physiology. W.B. Saunders, Philadelphia.

[29] National Heart Lung and Blood Institute. (2008) Fact Book. U.S Department of Health and Human Services, USA.

[30] Duren, D.L., Sherwood, R.J., Czerwinski, S., Lee, M., Choh, A.C., Siervogel, R.M. and Chumlea, Wm.C. (2008) Body Composition Methods: Comparisons and Interpretation. Journal of Diabetes Science and Technology, 2, 1139-1146. http://dx.doi.org/10.1177/193229680800200623

[31] Katzmarzyk, P.T., Janssen, I. and Ardern, C.I. (2003) Physical Inactivity, Excess Adiposity and Premature Mortality. Obesity Review, 4, 257-290. http://dx.doi.org/10.1046/j.1467-789X.2003.00120.x

[32] Cade, W.T. (2008) Diabetes-Related Microvascular and Macrovascular Diseases in the Physical Therapy Setting. Physical Therapy, 88, 1322-1335. http://dx.doi.org/10.2522/ptj.20080008

[33] Truswell, S.A. (2003) ABC of Nutrition. BMJ Publisher, London. 